\title{
Analysis of a Project Conducted on Unaccompanied Refu- gees Children (MERNAs)
}

\author{
Eva Aguaded-Ramírez ${ }^{1 *}\left(\mathbb{C}\right.$, Pierette Bartolomei-Torres² (), Georgia Angelidou ${ }^{3}$ \\ 'Department of Methods of Research and Diagnosis in Education, University of Granada, Spain \\ \{eaguaded@ugr.es\} \\ 2Department of Methods of Research and Diagnosis in Education, University of Granada, Spain \\ \{pierette18@correo.ugr.es\} \\ ${ }^{3}$ Department Methods of Research and Diagnosis in Education, University of Granada, Spain \\ \{g_aggelidou@hotmail.com\}
}

Received on 12 July 2017; revised on 19 November 2017; accepted on 10 January 2017; published on 15 July 2018

DOI: 10.7821/naer.2018.7.256

(cc) BY-NC-ND

\begin{abstract}
"An Unaccompanied Refugee children is a person under the age of 18 , who is afraid of being persecuted, whose rights are threatened and is forced to leave his / her habitual residence and / or country of origin and is outside it, without the accompaniment of parents, relatives or other adult person, who, by law or custom, is responsible. " (Angelidou \& Aguaded, 2016). According to the Human Rights Watch researches (2016), serious crimes against refugees and immigrants children are being committed. The Government of Spain announced that they expect to relocate a total of 586 people before the end of 2017 . At present, the number of refugees in Spain is more than 470. Specifically, Andalusia became, in September 2016, the first Spanish community that manages to relocate unaccompanied refugees children. The objective of this research is to analyze the socio-educational intervention, which is being carried out with these children. For this, the method used was in-depth interviews, y cuestionarios, which results offer very diverse information, from which we can conclude that there is a way forward, which is leading to improvements for children.
\end{abstract}

KEYWORDS: REFUGEES, CHILDREN, ANALYSIS, INTERVENTION, SOCIALIZATION

\section{PROJECT CONDUCTED ON UNNACOMPANIED REFUGEE MINORS}

This work presents an analysis of the characteristics of the project, which is being carried out in a Reception Center, with Unaccompanied Refugee Minors, particularly with the first minors with such characteristics, who have arrived into the peninsula and have been managed in a public registration centre Morales, Sanhueza, Friz y Riquelme. (2017).

To date, no research has been presented with the features of the present study, since, until now, there have not been Unaccompanied Refugee Minors arriving in Spain, in public reception centers. Furthermore, in other countries, which do manage such

\footnotetext{
*To whom correspondence should be addressed:

Departamento de Métodos de Investigación y Diagnóstico en Educación, Universidad de Granada Campus de Cartuja, S/N. 18071. Granada (España)
}

minors, investigators have not carried out research to understand if the rights and duties of the minors are being taken into account at these centers.

This research could specifically help other centers and, more generally, other countries through the design and planning of the project that will be conducted with this group, which provides a source of fundamental aid to agencies and institutions.

\section{INTRODUCTION}

Our work focuses on Unaccompanied Refugee Minors (from now on MRNAs). It is necessary to note the profile of these minors received in Europe; according to Carreras \& Forga (2015), is about children, who come from Syria, Afghanistan, and Iraq and most of them are under 12 years old. Regarding the numbers, still difficult to estimate, we follow the data of Save the Children, which shows that in the year 2015, approximately 270,000 refugee minors arrived in Europe and, among them, 26,000 children were unaccompanied (Ventoso, 2016; International Organization for Migration(OIM), 2017).

According to the Geneva Convention (1951) and the 1967 relevant Protocol, a refugee is a person who: due to well-founded fears of being persecuted for the reason of race, religion, nationality, membership of a particular social group or political opinion, is outside the country of his nationality. Moreover, because of such fears, cannot or does not wish to avail him/herself of the protection of his country. Either lacking nationality or being, as a consequence of such events outside the country, where he/she had his/her habitual residence, cannot, or because of such fears, he/ she does not want to return to it (Convention on the Status of Refugees, Art. 1A, 1951 as amended by the 1967's Protocol, United Nations, hereinafter N.U.).

In global terms, there is no definition, accepted by all, of what is considered to be a minor, so it is something that is determined by the legislation of each country. The General Comment No. 6, Committee on the Rights of the Child, Treatment of Unaccom- 
panied and Separated Children outside their country of origin, $39^{\circ}$ session period (2005), U.N.Doc. CRC-GC-2005-6 (2005) considers, in the same judgment, the unaccompanied minor as; a) unaccompanied children (also called unaccompanied minors), as defined in article 1 of the Convention, are resolved to mean minors who are separated from both parents and other relatives and are not cared for by an adult who, by law or custom, is the principal responsible.

b) separated children, within the meaning of the Convention, are defined as minors separated from either parents or their legal or customary guardians, but not necessarily from other relatives (Cabedo, 2010, p. 161).

\subsection{Project with Unaccompanied Refugee Minors (MERNAs)}

According to the definition of the United Nations International Children's Emergency Fund (hereinafter UNICEF, 2005), an Unaccompanied Minor is the national minor of a non-member state of the Union or the stateless person under 18 years old, who when entering European territory and is not accompanied by an adult. It shall also be any minor who is left alone after entering the territory of a member state of the European Union. When the adult declines his/her responsibility, once the child has entered Spanish territory, leaving them alone or even leaving them just before entering Spanish territory. Responsibility, which falls on the adult, may be in fact or law, meaning that it has been assumed by law or custom (Fuentes, 2014; Sánchez, 2014).

Furthermore, if we take into consideration the 1951 Geneva Convention, already mentioned, it states five causes or grounds for persecution, which recognize the right of asylum. We must add to this conception that the Unaccompanied Minor Refugee is the individual under 18 years of age, who is afraid of being persecuted, on the grounds of origin, sex, religion, nationality, membership of a particular social group or political opinions and beliefs. A minor whose rights are threatened and is forced to abandon his/her habitual residence and/or his/her country of origin, and is outside them, without the accompaniment of parents, relatives, or another adult person, who, by law or custom, is the principal responsible adult.

According to the United Nations High Commissioner for Refugees (hereinafter UNHCR, 2015) migrants move out of their countries in order to improve their lives and find work and / or education and not due to causes of direct threat of death or persecution. The children decide to migrate for economic and political reasons (Espuche, Luna, \& Dezalais, 2006; Davies y Batchelor, 2017; Fernández, Foussaier y Moreno, 2017), and also to save their lives, for example, Save the Children's report (2016) communicates that children who live in Syria, immigrate because they die of dehydration and malnutrition. According to the U.N., houses and streets are in ruins. Snipers shoot at anyone in the cities, and there are mines in the area and (Save the Children, 2016) the children suffer from infections and lung inflammations, due to smoke from bombs, diarrhea, mental illness and antisocial behavior (Courtney, 2017; Liddell, et al. 2017; Lindert, Von Ehrenstein, Wehrwein, Brahler y Schäfer, 2017; Wattsa, Mizindukoa, Barnettb, Whitec y Hochberga., 2017; Nejad, Klöhn-Saghatolislam, Hasan, y Pogarell, 2017; Wall, Campbell y Janbek, 2017; Elbert, Wilker, Shauer, \& Neuner, 2016; Miller, Hess, Bybee, y Goodkind, 2017; Rouhani, et al. 2017). Consequently, since the war in Syria and the crisis in the Arab countries began, Refugee Minors were added to foreign Unaccompanied Minors, according to Carreras \& Forga (2015).

According to Human Rights Watch investigations (herein- after HRW) (2015), serious crimes against refugee minors and immigrants are being committed; children may be detained, not only in transit countries such as Turkey and Greece but also in countries of final destination such as the United Kingdom and the Scandinavian countries. The cells where the refugees are detained are in deplorable conditions, which are far below international standards. Sometimes, children are required to stay in detection centers, in cells with other adults, who they are unfamiliar with, and with whom they cannot communicate (Farmer, 2013).

Given these situations, the European Union and other countries have taken a stand and some, such as Spain; have decided to take action, where the commitment of acceptance of refugees from the war in Syria is 16,000 people. The Government of Spain has already announced that it expects to relocate a total of 586 people before the end of 2017 (150 from Greece and 50 from Italy, 386 from Lebanon and 101 from Turkey). Currently, the number of refugees in Spain is more than 490 and it is necessary to reflect on the project process carried out with the children under guardianship, as Figueredo, García y Sánchez (2017) have done.

Among them, the first MERNAs have arrived in Andalucía; specifically, seven Syrian minors have arrived in Motril, Granada in search of a home, from refugee camps in Greece or Italy. Now, in Spain, they will live in a protected children's center, coordinated by the SAMU Foundation in Motril, as a result of an initiative organized by this association with the assurance of the Andalusian Government, which has guarded the children in a project acclaimed by The UN Refugee Agency (UNHCR). The project will culminate in the protection of a total of 24 children, some of them siblings, who will not be separated due to a unification program. The location of the parents of these five boys and two girls, between 14 and 17 years old, is diverse; some are still in refugee camps, while others have disappeared in the city of Damascus (Syria). Meanwhile, tutors who guide them in the acclimatization process and the knowledge of the language, remain at the center.

\section{MATERIAL AND METHODS}

A descriptive, mixed-cut investigation has been carried out. SAMU Foundation Directors have been interviewed, and questionnaires have been conducted with professionals, who perform the project at the SAMU Motril Orientation and Social Work Insertion Center and on the minors assisted.

Three people from the Foundation participated (three men with professional experience with foreign minors over 5-9 years), five professionals from the Reception Center (4 women and 1 man with professional experience of foreign minors between 6 months and 9 years), and seven MERNAs (all male, ages 12-17 old and all from Syria), who have been sheltered since September 2016, being the first to arrive in a Spanish Autonomous Community. As in the case of the Directors of the Foundation, and the one of the MERNAs, there has not been a sample selection process, since all have participated. Regarding the case of the professionals, the sampling has been incidental, since it has been conducted on those to whom we have had access, not having been influenced by the 'willingness factor' or the wish to not to participate, but the access to the person, since they are organized in shifts.

The general objective of the present investigation is to know if it is adequate and if it fulfills the rights of the MERNAs, who are assisted in the Reception Center. The general objective is set out in different specific objectives, which are:

(1) To know the characteristics of the project carried out, by the managers of the Reception Center. 
(2) To know the features of the project conducted, by the professionals at the Reception Center.

(3) To know the perception of the MERNAs, regarding the project that is performed by the Reception Center.

All the data collection instruments were conducted between the months of January-March 2017, when the children had been in the Reception Center for 4 to 6 months.

Regarding the interview, this was passed to the members of the Foundation and was elaborated by Zuriñe, used Martín and Amadou Coulibaly (2010) and adapted by Angelidou y Aguaded (2017) for MENAs' reception centers; as shown in Table 1:

Table 1. Interview with the directors of the Foundation

1. Is this facility a first place reception, residential, immigrant-specific or mixed centre?

2. What was the number of total places at the center in the year 2016-7?

3. What is the number of specific accommodation places available for MERNAs?

4. What is the current number of refugee children in the center?

5. What is the current number of refugee minors in the centers, specifically by gender?

6. What is the current age of the MERNAs?

7. What are the nationalities of the MERNAs?

8. Do MERNAs provide any provisional documentation to the center on entry?

9. What is the number and professional category of technical and educational personnel in direct care with Unaccompanied Refugee Minors?

10. What is the number of professionals - internal or external - who know the language of the children?

11. Does the center's educational staff and general service staff receive specific training?

Also, as previously mentioned, the professionals at the Reception Center were given a questionnaire, which was elaborated by Zuriñe, used Martín and Amadou Coulibaly (2010) and adapted by Angelidou y Aguaded (2017).. The questionnaire was validated in Martín and Coulibaly's research (2010). On the other hand, to determine reliability, we used the statistical program SPSS version 22.0 through the Cronbach alpha coefficient. According to the analysis, Cronbach's alpha is very high $(\alpha=0.848)$, consequenlty we can trust the results of the analysis.

It has a total of 46 items; some of them are presented in Table 2. The items had to be answered in a multiple-choice selection. Also, as we mentioned earlier, the professionals at the Reception Center were given a questionnaire, which was a modification of the one used by Angelidou \& Aguaded (2017). It has a total of 46 items; some of them are presented in Table 1 of Appendix. The items had to be answered in a multiple-choice selection, from which, they could choose one of the following options. The items were grouped around the following categories:

(1) Information about their rights

(2) Relationship with the center's educators
(3) Respect for the privacy and daily routine in the centers

(4) Assessing the Reception Center as a pleasant or an unpleasant place

(5) Food and clothing

(6) Use of the language

(7) Religion

(8) Penalties and sanctions regime

(9) Participation

(10) Free time and organized activities

(11) Communication with the outside world

(12) Relations with the outside world and preparation for departure

In the case of the questionnaire applied to MERNAS, the adaptation of an initial one, applied to MENAs, (Angelidou \& Aguaded, 2016) was validated and used. According to the analysis, Cronbach's alpha is very high $(\alpha=0.868)$ which means we can trust the results of the analysis. It was done in a particular way, due to the difficulty of the language. Consequently, we had to be present during its application, to ensure the translation collected the necessary information. This questionnaire contains 69 items, questions are asked about the project being performed in the center; some examples of such items are presented in Table 2. The categories used for the design of the items are as follows:

(1) Reception at the Reception Center.

Reception by the Foundation's Management Team.

(2) The given quality of professional work and respect for minors.

(3) Difficulties relating to their language.

(4) Difficulties in the relationship with their fellow companions.

(5) Respect for their religion and privacy.

(6) Difficulties in the relationship with the native population.

(7) Punishments and penalties.

(8) Fulfillment of departures.

(9) Sufficient provision of clothes to their liking.

Table 2. Examples of items from the questionnaire administered to the MERNAs

1. Did you receive information about the rules of the center when entering the center?

\begin{tabular}{ll}
\hline$\cdot$ Yes \\
\hline$\cdot$ No \\
\hline Nonresponse \\
\hline
\end{tabular}

2. Were you provided with information about your rights and obligations when entering the center?

\begin{tabular}{ll}
\hline Yes \\
\hline - No \\
\hline Nonresponse \\
\hline
\end{tabular}


3. Did you receive information about the rights and responsibilities of educators upon your entry at the center?

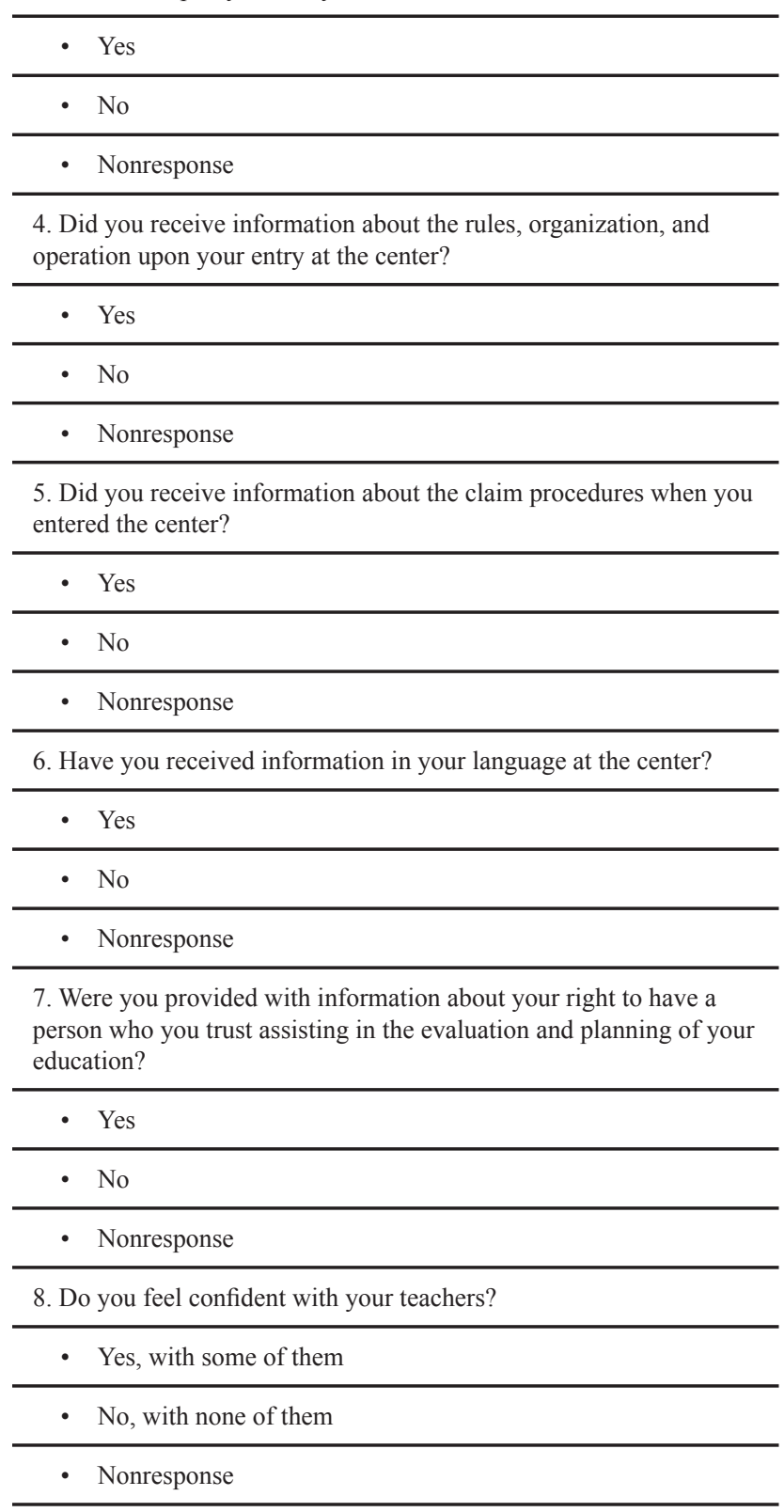

\section{RESULTS}

Regarding the interviews conducted on the Directors of the Foundation, we can state the Directors of the Foundation were informed, at all times, of the characteristics of the MERNAs and all the places, actions, services and resources were prepared for their first reception and the project. Additionally, programming the reception of the MERNAs was carefully planned and adapted to their characteristics. We state it taking into account that the project was carried out in a planned and supervised way by all authorities; European, Spanish and Andalusian and, as it happened to be the case, of the analyzed minors, the first in the Spanish State. Regarding the questionnaires given to the professionals of the Reception Center, we highlight the following information:

\section{Information about their rights}

According to the research, when asked if the MERNAs received information about the rules from the center upon entering it, $90 \%$ of the workers answered yes. Also, $75.7 \%$ of the workers responded that the MERNAs received information about their rights and responsibilities. In the question, whether the MERNAs were provided with information in their language at the center, $37.1 \%$ answered positively, with the aid of the translator; the rest of them answered 'I do not know / nonresponse'.

\section{Relationship with the center's educators}

$81.4 \%$ of the workers believe that all educators manage children with respect, while the rest believe that not all of them take minors into consideration.

In cases where the children ask questions or disagree with them, the majority of the respondents (47.1\%) answered that all the workers try to solve the inquiries of the MERNAs. $61.4 \%$ of them believe there is a good relationship between the tutors and the MERNAs.

According to the question, of whether the MERNAs can speak easily with the coordinator, $64.7 \%$ of the respondents responded that this is the case.

\section{Regarding privacy and daily routine in the centers}

All the respondents answered that the educators knock on the door before entering every child's room. Thus, the minors right to privacy is indeed fulfilled in reality.

$100 \%$ of the respondents answered that children could shower in the center and also, they have room to be able to study.

Regarding the sleep hours, $81.4 \%$ responded minors could sleep 8 hours and more.

4. Assessing the Reception Center as a pleasant or an unpleasant place

The asked question, if in general, the center is pleasant for the minors, $81.4 \%$ of the educators answered yes.

\section{Food and clothing}

Regarding the question concerning whether the nutritional diet is respected, $100 \%$ of the respondents answered yes, it is valued, and the children are not obligated to eat non-halal meat against their will. As for the question, if MERNAs are required to eat all the food that is served, the respondents have different opinions. $62.9 \%$ believe children are forced to eat all the food that is served.

As for the question whether educators believe that clothing and footwear, which is provided at the center for minors, is sufficient, $81.4 \%$ believes it is.

\section{Use of the language}

Regarding the utilization of the mother tongue, all the respondents answered that it is not forbidden for the MERNAs to speak their native language with their peers, and they believe that sufficient guidance is given to the children so they can learn Castilian adequately.

\section{Religion}

According to the research, religious and cultural practices are entirely respected in the Reception Center. $100 \%$ of the respondents contested that the culture and religion of the MERNAs are respected, and minors have the opportunity to pray at the Center.

\section{Penalties and punishments regime}

Concerning the sanctions imposed on children, the majority of respondents $(81.4 \%)$ believe they are always or almost always fair. Also, all respondents think MERNAs have the chance of explaining themselves when they have sanctions imposed on them. As for the question, of whether any child has been put in isolation as a punishment; $47.1 \%$ answered no, and $52.9 \%$ answered I do not know/nonresponse. 


\section{Participation}

$75.7 \%$ of those questioned have responded that the children state their opinions when decisions that affect their lives have to be made.

As for the question of whether the MENAs are guided to make their educational plan, the vast majority of workers seem to have no information about this, since $87.1 \%$ said they do not know/ nonresponse.

\section{Free time and organized activities}

According to the workers of the center, $81.4 \%$ responded they guide the minors when participating in some cultural / sports activity outside the center.

$100 \%$ of the respondents answered there are more leisure activities available than only football.

Concerning the administration of the time of minors, $84.7 \%$ of them believed children had enough free time.

\section{Communication with the outside world}

Regarding access to the telephone, respondents (37.1\%) believe minors have access to make phone calls, and the rest of them answered that they do not know/nonresponse. According to the results of the investigation, it seems that $84.1 \%$ of the workers help the children to call their relatives or friends who are in their country of origin, one person answered that they do not, and one person answered do not know/nonresponse.

All respondents $(100 \%)$ replied that the children have access to the Internet in the Center; they have the possibility of receiving both, phone calls and visits, from family or friends at the Center.

12. Relations with the outside world and preparation regarding the departure.

$100 \%$ of the respondents answered that the children are taught about the city and social resources. As for the question of facilitating or avoiding contact between Unaccompanied Refugee Minors and the outside town, $51.4 \%$ believe it is facilitated.

$45.7 \%$ of workers think that the Center promotes the relationship between MERNAs and people from the city. Finally, regarding the question of whether before the Refugee Minor reaches 18 years, they help them to prepare his/her exit to integrate into Granada (if he/she wishes) $41.7 \%$ answered yes they help him/her.

Finally, from the results obtained from the 7 questionnaires passed to the MERNAS, we highlight the following results:

(1) The children consider they have been well received in the Reception Center (7 yes, 100\%).

(2) They also believe the Foundation's Management Team has welcomed them very well (7 yes, 100\%).

(3) They think the professionals do their job well and treat them with respect ( 6 yes, $85,7 \%$ ).

(4) The minors think their tutors have difficulty relating to them in their language, although they end up getting along with them (5 yes, $71.4 \%)$.

(5) They believe that they do have problems relating to the rest of their companions, who are in the center of reception (6 yes, $85.7 \%$ ).

(6) They think their religion and their privacy are respected (7 yes, 100\%).

(7) They replied they have difficulty in relating to the native population (4 yes, 57.1\%).

(8) The children answered that they do not suffer punishment and sanctions are usually fair ( 7 yes, 100\%).

(9) They take trips outside, which helps them to know their surroundings (7 yes, 100\%).

(10) They have enough clothes, which they really like (7 yes, $100 \%)$.

\section{DISCUSSION}

Aligning with the research data on MENAs (Angelidou \& Aguaded, 2016), both managers and professionals say the project conducted with the minors is adequate and functional (Annual Report of Minors 2014; Annual Report Of Minor Supporter from Andalusia 2015, Special Report the Attention to Minor Offenders in Andalusian Internment Centers, 2014), in each of the aspects analyzed. However, regarding the MERNAs' expressions about how they perceive the project that is being carried out in the Reception Center; we find the minors answer that they are satisfied with the project. Meanwhile, when other investigations conclude that the projects conducted on MERNAs in other countries violate the Rights of the Child (HRW, 2015), although they present some difficulties in different aspects, since they think that their tutors have difficulty relating to them in their language, have problems of relating to other companions, they have difficulty in relating to the native population.

The managers consider that the investigation is adequate and efficient, as it happens in the case of professionals.

\section{CONCLUSIONS}

On the basis of the findings reported and regarding the first specific objective (To know the characteristics of the project conducted by the managers of the Reception Center.), obtained with the interview of the Management Team, we can highlight that the management of the reception of the MERNAs has been very well planned and adapted to their characteristics.

From the conclusions, regarding the second of the specific objectives, (To know the features of the project made, by the professionals of the Reception Center) obtained from the results of the questionnaire passed to the professionals, we can state the characteristics of the project. They are the following: the minors are informed in their language about the rules and their rights. Also, the relationship with the children is good. The Center staff are respectful of their language, customs, and religion, the minors are allowed to participate and are given free time, which they use for trips.

Regarding the third of the specific objectives (To Know the Perception of the MERNAs, regarding the project that is carried out by the Reception Center.), whose data has been collected with the questionnaire passed to MERNAs, we emphasize that both reception and receiving are adequate. Also, we conclude professionals do their work well, respecting their religion and privacy and the main difficulties are in relating to others inside and outside the center, especially because of their language.

As a general conclusion, we can say the project carried out on the MERNAs is adequate and complies the rights of the minors, from the perspective of the three agents involved: managers, professionals, and children, although it is still pending to resolve some difficulties generated by the ignorance of the language of the minors, by the professionals and the rest of the colleagues at the center and by the lack of knowledge of Spanish by the MERNAs. In addition, an adequate project is necessary in relation to the inclusion of minors in the target population. 


\section{REFERENCES}

Angelidou, G. \& Aguaded, E. (2016). Los derechos de los menores extranjeros no acompañados en los centros de menores. REIDOE, 2(2), 4-20.

Angelidou, G., \& Aguaded, E. (2017). Menores extranjeros no acompañados. Un fenómeno relevante en la sociedad española. Revista de Educación de la Universidad de Granada, 24, 47-63.

Cabedo, V. (2010). La situación de los menores inmigrantes no acompañados. Su protección e integración. Valencia: Tirant lo Blanch. Retrieved from https://issuu.com/tirantloblanch/docs/e26baaf8fabf1b4dd37f887147f2b042

Carreras, T., \& Forga, M. (2015). Un drama con rostro de niño: Más de la mitad de los refugiados sirios en Turquía son menores. El siglo de Europa, 1221, 46-48.

Courtney, J. (2017). Muslim refugees in the United States: how god views them and desires the church to follow in obedience. Global Missiology English, 4(14), $1-16$

Davies, S., \& Batchelor, C. (2017). El reasentamiento como instrumento de protección para niños refugiados. Revistas - Migraciones Forzadas, 54, 38-41.

Defensor del Menor de Andalucía (2014). Informe anual del Defensor del Menor de Andalucia 2014. Retrieved from http://www.observatoriodelainfancia.es/oia/ esp/documentos ficha.aspx?id=4967

Defensor del Menor de Andalucía (2014). Informe especial la atención a menores infractores en centros de internamiento de Andalucía. Retrieved from http://www.juntadeandalucia.es/export/drupaljda/Informe $\% 20$ Especial $\% 20$ Menores\%20Infractores_ok.pdf

Defensor del Menor de Andalucía (2015). Informe anual del Defensor del Menor de Andalucia 2015. Retrieved from http://www.defensordelmenordeandalucia. es/node/10745

Elbert, T., Wilker, S., Schauer, M., \& Neuner, F. (2016). Dissemination of psychotherapy modules for traumatized refugees: Experience gained from trauma work in crisis and conflict regions. Europe PMC, 88(1), 26-33.

Espuche, B., Luna, C., \& Dezalais, B. (2006). Entre la represión y la protección. Menores extranjeros no acompañados en Andalucía. Andalucía: Asociación pro Derechos Humanos de Andalucía.

Farmer, A. (2013). El impacto de la detención migratoria en los niños. Revista Migraciones Forzadas, 44, 4-16.

Fernández, I, Fouassier, M., \& Moreno, G. (2017). Una propuesta integral de medición de las migraciones forzadas. El caso de la población de origen colombiano en el País Vasco. OBETS. Revista de Ciencias Sociales, 12(1), 15-39.

Figueredo, V., García, P., \& Sánchez, A. (2017). Estrategias y límites en la inserción sociolaboral con menores extranjeros no acompañados en el marco de los centros de protección: el caso de Almería. InterSciencePlace. Revista Científica Internacional, 12(1), 64-173.

Fondo de las Naciones Unidas para la Infancia (UNICEF) (2005). Treatment of unaccimpanied and separated children outside their country of origin. Retrieved from https://www.unicef.org/protection/files/CRCGC6_EN.pdf

Fuentes, R. (2014). Menores extranjeros no acompañados (MENA). Azarbe. Revista Internacional de Trabajo Social y Bienestar, 3, 105-111

Human Rights Watch (2015). Derechos de los Refugiados. Retrieved from https:// www.hrw.org/es/topic/derechos-de-refugiados

Lee, D., Weinberg, M., \& Benoit, S. (2017). Evaluation of measles-mumps-rubella vaccination among newly arrived refugees. American Journal of Public Health, 107(5), 684-686. doi:10.2105/AJPH.2017.303698

Liddell, B., Cheung, J., Den, M., Felmingham, K., Malhi, G., Das, P., Nickerson, A., Askovic, M., Aroche, J, Coello, M., \& Bryant, R. (2017). Biological Psychiatry, 81(10), Supplement. doi:10.1016/j.biopsych.2017.02.384

Lindert, J., Von Ehrenstein, O. S., Wehrwein, A., Brahler, E., \& Schäfer, I. (2017). Anxiety, depression and posttraumatic stress disorder in refugees -a systematic review. Psychother. Psychosom. Med. Psychol, 68(1), 22-29.

Martín, Z., \& Coulibaly, A. (2010). Situación de los centros de acogida temporal para menores extranjeros no acompaña-dos. Vitoria-Gasteiz: IKUSBIDE. Retrieved from http://www.ikusbide.org/data/documentos/SITUACION.pdf

Miller, A., Hess, J. M., Bybee, D., \& Goodkind, J. R. (2017). Understanding the mental health consequences of family separation for refugees: implications for policy and practice. American Journal Orthopsychiatric.

Morales, K., Sanhueza, S., Friz, M., \& Riquelme, P. (2017). The intercultural sensitivity of chilean teachers serving an immigrant population in schools. Journal of New Approaches in Educational Research, 6(1), 71-77. doi:10.7821/ naer.2016.8.173

Naciones Unidas (1951). Convención de 1951 y de su Protocolo de 1967. Retrieved from http://www.acnur.org/el-acnur/historia-del-acnur/la-convencion-de-1951/

Naciones Unidas (2005). Comité de los Derechos Niño, Trato de los menores no acompañados y separados de su familia fuera de su país de origen, $39^{\circ}$ período de sesiones U.N.Doc. CRC/GC/2005/6

Nejad, R., Klöhn-Saghatolislam, F., Hasan, A., \& Pogarell, O. (2017). Mental disorders and problems in afghan refugees: The clinical perspective. MMW Fortschr Med, 159(9), 64-66. doi:10.1007/s15006-017-9653-y
Organización Internacional de las Migraciones (IOM) (2017). Mediterranean update. Migration flows Europe: Arrivals and fatalities. Retrieved from https:// reliefweb.int/report/italy/mediterranean-update-migration-flows-europe-arrivals-and-fatalities-03-october-2017

Rouhani, Sh., O'Laughlin, K., Faustin, Z., Tsai, A., Kasozi, J., \& Ware, N. (2017). The role of social support on HIV testing and treatment adherence: A qualitative study of HIV-infected refugees in southwestern Uganda. Journal Global Public Health, 12(8). doi:10.1080/17441692.2015.1132472

Sánchez, M. B. (2014). Tratamiento e integración de los menores extranjeros no acompañados. In S. Jiménez, J. D. Gutiérrez, H. Carrasco, \& P. González (Eds.), Actas de comunicaciones. Encuentros Internacionales con menores en contextos de riesgo (pp. 91-109). Retrieved from http://www.pensamientopenal.com.ar/ system/files/2015/11/doctrina42446.pdf

Save the Children (2016). Infancia bajo asedio. Vivir y morir en las zonas asediadas en Siria. Save the Children.

UNHCR (2015). ¿'Refugiado'o 'migrante'? ACNUR insta a usar el término correcto. (27/08/2015). n UNHCR - ACNUR. Retrieved from http://www.acnur.org/ noticias/noticia/refugiado-o-migrante-acnur-insta-a-usar-el-terminocorrecto/

Ventoso, L. (February 1, 2016). Europol denuncia la desaparición de diez mil niños refugiados. $A B C$. Retrieved from http://ghctnoticias.com/index.php/internacional/8084-europol-denuncia-ladesaparicion-de-diez-mil-ninos-refugiados

Wall, M., Campbell, M., \& Janbek, D. (2017). Syrian refugees and information precarity. New Media \& Society, 19(2), 240-254. doi:10.1177/1461444815591967

Wattsa, N., Mizindukoa, M., Barnettb, E., Whitec, L., \& Hochberga, N. (2017). Association between parasitic infections and tuberculin skin test results in refugees. Travel Medicine and Infectious Disease, 16, 35-40. doi:10.1016/j. tmaid.2017.03.007

How to cite this article: Aguaded-Ramírez, E.; Bartolomei-Torres, P.; Angelidou, G. (2017). Analysis of a Project Conducted on Unaccompanied Refugees Children (MERNAs). Journal of New Approaches in Educational Research, 7(2), 116-124. doi: 10.7821/naer.2018.7.256

\section{APPENDIX}

Table 1. Sample items of the Questionnaire addressed to the professionals at the Reception Centre

1. Did the Unaccompanied Minor Refugees receive information about the rules of the center on entry?

- Yes

- No

- I do not know/nonresponse

2. Did Unaccompanied Refugee Minors receive information about their rights and responsibilities when entering the center?

- Yes

- No

- I do not know/nonresponse

3. Have Unaccompanied Refugee Minors received information in their mother tongue at the center?

- Yes

- No

- I do not know/nonresponse

4. Generally speaking, do you believe that Unaccompanied Refugee Minors feel confident with their educators?

- Yes

- No 


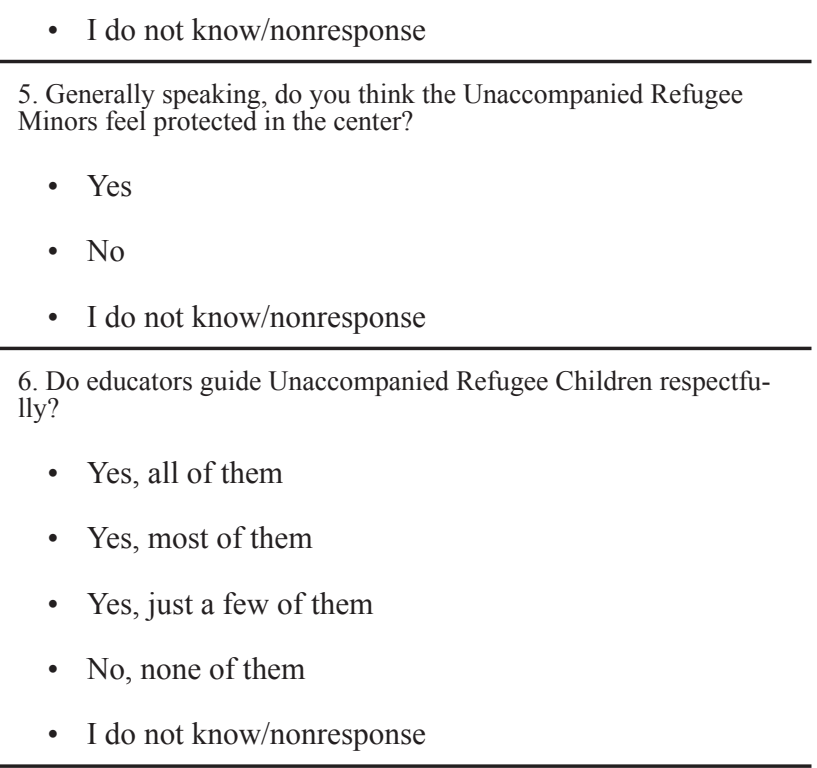

7. Do educators respond politely to Unaccompanied Refugee Minors when they ask questions or show disagreement?

- Yes, all of them

- Yes, most of them

- Yes, just a few of them

- No, none of them

- I do not know/nonresponse

8. In general, do you believe that Unaccompanied Refugee Minors feel at ease when telling teachers their concerns?

- Yes, to all of them

- Yes, to most of them

- Yes, just a few of them

- No, to none of them

- I do not know/nonresponse

9. Are educators solely employed to educate Unaccompanied Refugee Minors, or do they have other functions?

- Yes, they solely educate them

- No, they have other functions

- I do not know/nonresponse

10. In general, is there a good relationship between the tutor and the Unaccompanied Refugee Minor?

- Yes

- No

- With some of them yes, with others, no

- I do not know/nonresponse

11. Can Unaccompanied Refugee Minors talk efficiently with the coordinator?
- Yes

- No

- I do not know/nonresponse

12. Do tutors knock on the door before entering the room of an Unaccompanied Refugee Minor?

- Yes

- No

- Sometimes

- I do not know/nonresponse

13. Do the bedrooms remain closed during the day?

- Yes

- No

- I do not know/nonresponse

14. Is it possible for the Unaccompanied Refugee Minors to shower in the center?

- Yes

- No

- I do not know/nonresponse

15. Do the Unaccompanied Refugee Minors have a room in which to study?

- Yes

- No

- I do not know/nonresponse

16. How many hours can the Unaccompanied Refugee Minors sleep during the night?

- 8 hours or more

- Between 7 and 8 hours

- Between 6 and 7 hours

- Less than 6 hours

- I do not know/nonresponse

17. In general, for the Unaccompanied Refugee Minors, is the Center;

- A pleasant place

- An unpleasant place

- It depends

- I do not know/nonresponse

18. Are the religious dietary requirements of the Unaccompanied Refugee Minors respected?

- Yes

- No 
- I do not know/nonresponse

19. Are they obliged to eat all the food served?

- Yes

- No

- I do not know/nonresponse

20. Do you think the clothing and footwear provided at the center are sufficient for the Unaccompanied Refugee Minors?

- Yes

- No

\section{- I do not know/nonresponse}

21. Are Unaccompanied Refugee Minors forced to eat non-hala meat against their will?

- Yes

- No

- I do not know/nonresponse

22. Do you believe that sufficient help is given to Unaccompanied Refugee Minors so they can learn Spanish adequately?

- Yes

- No

- I do not know/nonresponse

23. Are they forbidden to speak in their mother tongue to their classmates?

- Yes

- No

- I do not know/nonresponse

24. Has an unaccompanied minor refugee been punished for speaking in his/her first language?

- Yes

- No

- I do not know/nonresponse

25. Do Unaccompanied Refugee Minors have the opportunity to pray at the center?

- Yes

- No

- Sometimes

- I do not know/nonresponse

26. Do you think their culture and religion are respected?

- Yes

- $\mathrm{No}$

- Sometimes
- I do not know/nonresponse

27. If an Unaccompanied Refugee Minor has been reported because of a false passport, has he/she received legal advice?

- $\mathrm{He} / \mathrm{She}$ was convicted and did not received legal advice

- He/She was convicted and received legal advice

- There have been no such reports

- I do not know/nonresponse

28. I believe the sanctions imposed at the center are;

- always or almost always fair

- almost always unfair

- always unfair

- I do not know/nonresponse

29. Do Unaccompanied Refugee Minors have the opportunity to explain themselves when they have sanctions?

- Yes

- No

- I do not know/nonresponse

30. Has any Unaccompanied Refugee Minor ever been placed in isolation or a similar location as a punishment and if so, for how long?

- $\mathrm{No}$

- Yes, for less than 2 hours

- Yes between 2 and 6 hours

- Yes, for more than 6 hours

- I do not know/nonresponse

31. Do Unaccompanied Refugee Minors give their opinions when decisions that affect their lives are made?

- Yes

- No

- I do not know/nonresponse

32. Do Unaccompanied Refugee Minors participate in the development of their educational plan?

- Yes

- No

- I do not know/nonresponse

33. Are unaccompanied refugee children guided when involved in any cultural/sports activity outside the center?

- Yes

- No 
- I do not know/nonresponse

34. Are there other leisure activities other than playing football?

- Yes

- No

- I do not know/nonresponse

35. Is playing soccer a mandatory activity?

- Yes

- No

- I do not know/nonresponse

36. Do you consider that Unaccompanied Refugee Minors have sufficient free time from Monday through Friday, to do whatever they want?

- Yes, they have enough

- No

- Less than 1 hour per day

- Between 1 and 2 hours per day

- I do not know/nonresponse

37. Do Unaccompanied Refugee Minors have spare time on the weekends?

- No

- Between 1 and 2 hours at weekend

- Between 2 and 4 hours at weekend

- Between 4 and 6 hours at weekend

- Between 6 and 8 hours at weekend

- I do not know/nonresponse

38. Do the Unaccompanied Refugee Minors have access to the telephone in the center?

- Yes

- No

- I do not know/nonresponse

39. Do you help Unaccompanied Refugee Minors to call their families or friends who are in their country of origin?

- Yes

- No

- I do not know/nonresponse

40. Do Unaccompanied Refugee Minors have access to the internet at the center?

- Yes

- No

- I do not know/nonresponse
41. Can the Unaccompanied Refugee Minors receive phone calls at the center?

- Yes

- No

- I do not know/nonresponse

42. Do Unaccompanied Refugee Minors have the opportunity to receive visits from family or friends at the center?

- Yes

- No

- I do not know/nonresponse

43. Are the Unaccompanied Refugee Minors taught about the city and its social resources by the center?

- Yes

- No

- I do not know/nonresponse

44. Is contact between Unaccompanied Refugee Minors and the outside world facilitated or avoided by the center?

- It is facilitated

- It is prevented

- I do not know/nonresponse

45. Is the relationship between Unaccompanied Refugee Minors and people facilitated?

- It is facilitated

- It is prevented

- I do not know/nonresponse

46. Before the Unaccompanied Refugee Minor becomes 18 years, old do you help him/her prepare for his/her departure to join Granada if he/she wishes?

- Yes

- No

- I do not know/nonresponse 